\title{
Spatial and temporal variations of the ectoparasites of seven reef fish species from Lizard Island and Heron Island, Australia
}

\author{
Alexandra S. Grutter \\ Department of Marine Biology, James Cook University of North Queensland, Townsville, Queensland 4811, Australia
}

\begin{abstract}
Spatial and temporal variations in abundance of ectoparasites from 7 coral reef fish species [Hemigymnus melapterus (Labridae), Siganus doliatus (Siganidae), Scolopsis bilineatus (Nemipteridae), Thalassoma lunare (Labridae), Scarus sordidus (Scaridae), Ctenochaetus striatus (Acanthuridae), and Acanthochromis polyacanthus (Pomacentridae)] at 2 locations, Lizard Island and Heron Island in the Great Barrier Reef, were investigated. The study demonstrates that there is a significant species-specific parasite fauna which is conserved over space and time. Host identity explained most of the variation in parasite composition and abundance while host size explained a smaller proportion of the variation. For each species the parasite assemblage showed little variation among local, but physically varied, sites. Species-specific patterns of parasite abundance were similar between widely separated locations, although there were more categories of parasites at the northern location, Lizard Island. Parasite numbers and species composition among fish species at Lizard Island did not vary among collection times except for $S$. doliatus, which had a 7 -fold increase between May 1992 and January 1993, mainly due to dactylogyridean monogeneans. Parasite abundance was positively correlated with fish standard length for 3 fish species.
\end{abstract}

KEY WORDS: Ectoparasites - Coral reef fish - Spatial variation - Temporal variation - Great Barrier Reef

\section{INTRODUCTION}

The numbers and species composition of marine ectoparasites vary both among and within fish species. Variation in parasites within a species can occur on a small spatial scale (Yeo \& Spieler 1980) or on a large spatial scale latitudinally (Dogiel 1961, Polyanski 1961b, Rohde 1977). Parasites also vary seasonally (Kennedy 1975) and as a function of host size (Bortone et al. 1978). These sources of variation can confound results and therefore must be considered in parasitological studies.

Estimates of spatial variation are needed when designing sampling programs in order to obtain reliable estimates of parasites. Before large-scale spatial comparisons among locations can be made, estimates of small-scale spatial variation among sites are needed to avoid confounding effects. Estimates of small-scale variation are also important if fish collections are logistically constrained. For example, if some fish species are more easily collected at some sites than others, knowledge of the spatial variability among sites will determine whether sampling can be reduced to particular sites or combined among sites.

Information on the temporal variability of parasites is needed to establish whether observed parasite fauna is representative of overall parasite fauna. Temporal variability in parasites can also affect the factors they influence. For instance, the diet of cleaner fish or the cleaning behavior of fish hosts could change if the parasite loads of fish change over time. Studies of temporal variation in fish parasites have been largely confined to cold temperate seas (Llewellyn 1959, Noble et al. 1963, Kennedy 1975, Rawson 1976), with the few studies in the tropics restricted mostly to the parasites of snails (Rohde \& Sandland 1973, Cannon 1978, 1979, Rohde 1981).

The diversity of coral reef fishes found in the Great Barrier Reef is high (Randall et al. 1990). The diversity of monogenean parasites in the Great Barrier Reef is almost certainly greater than that of fish species 
(Rohde 1977) and the number of parasite species at Heron Island alone has been estimated at 20000 (Rohde 1977). If both parasite fauna and fish are diverse, the potential for variability in the interactions between fish and parasites is high. Such questions require estimates of how parasites vary amongst species and the degree to which they are constant over space and time. This information is relevant not only for this type of study, but also for other parasitological work such as in fish stock discrimination (Lester et al. 1988) and evolution (Brooks \& McLennan 1993).

Much parasitological work is observational or descriptive and thus tends to be non-quantitative (Sindermann 1986). This study is quantitative rather than qualitative with the emphasis placed on measuring the variability in numbers of parasites using broad categories of ectoparasites. The complete ectoparasite faunas of 7 relatively small fish species which are common on coral reefs of the Great Barrier Reef are quantified. The variations in ectoparasite numbers and species composition among fish species, sites, locations, and times of collection, as well as the relationship between host size and parasite abundance, were investigated. The species span a range of taxonomic and ecological relationships but are all common in shallow coral reef waters. This study forms part of broader study on the feeding biology of cleaner fish.

\section{MATERIALS AND METHODS}

The fish species investigated were Hemigymnus melapterus (Labridae), Siganus doliatus (Siganidae), Scolopsis bilineatus (Nemipteridae), Thalassoma lunare (Labridae), Scarus sordidus (Scaridae), Ctenochaetus striatus (Acanthuridae), and Acanthochromis polyacanthus (Pomacentridae). The species were selected because they live in similar habitats and are relatively abundant and easy to capture. All species have different feeding habits, and $3(H$. melapterus, T. lunare, $S$, sordidus) are taxonomically related and belong to the order Labroidei (sensu Greenwood et al. 1966). A total of 304 fish were collected.

Sampling design. Spatial variation was examined at 2 scales, within a reef system. (Lizard Island) incorporating different habitats and between reef systems separated by $1000 \mathrm{~km}$ (Lizard Island and Heron Island). Small-scale variation was examined at 3 sites ( 1 to $5 \mathrm{~km}$ apart) located around Lizard Island which are in shallow coral reefs ( 2 to
$7 \mathrm{~m}$ ) and have different levels of wave exposure. Site 1 (North Point) is the most exposed, Site 2 (Granite Bluff) is less exposed, and Site 3 (Lagoon) is in a protected lagoon behind a small island and has little wave exposure. The differences among sites are reflected in the fish fauna (Choat \& Bellwood 1985).

Lizard Island $\left(14^{\circ} 40^{\prime} \mathrm{S}, 145^{\circ} 26^{\prime} \mathrm{E}\right)$ and Heron Island $\left(23^{\circ} 27^{\prime} \mathrm{S}, 151^{\circ} 55^{\prime} \mathrm{E}\right)$ are approximately $1000 \mathrm{~km}$ apart, with Lizard Island located in the northern part of the Great Barrier Reef and Heron Island in the southern part. Lizard Island is a continental island with fringing reefs while Heron Island is a coral cay with a large platform reef. The locations were selected because they represent reef systems at the extremes of the Great Barrier Reef, yet both have the species investigated. Fish were collected at 3 times (seasons) from Lizard Island (May 1992, August 1992, and January 1993) and once from Heron Island (June 1993).

Sites. To investigate the number and composition of parasites (Table 1) among fish species collected from different sites, 5 to 9 fish per site from 3 sites were collected from each species in May 1992. Specimens of

Table 1. Parasite categories and codes used for classifying ectoparasites from 7 coral reef fishes. Bold headings are broad descriptions of categories. See 'Materials and methods' for details on species

\begin{tabular}{|c|c|c|}
\hline Code & Species & Size range \\
\hline \multicolumn{3}{|c|}{ Copepoda } \\
\hline HatH & Hatschekia hemigymni & $280 \mu \mathrm{m}$ to $1 \mathrm{~mm}$ \\
\hline HatA & Hatschekia sp. a & 1.9 to $2.3 \mathrm{~mm}$ \\
\hline Bomo & $\begin{array}{l}\text { Acanthocolax sp. nov. males and/or } \\
\text { Orbitacolax sp. nov. males }\end{array}$ & 540 to $7.10 \mu \mathrm{m}$ \\
\hline Orbi & Orbitacolax sp. nov. females & $71.0 \mu \mathrm{m}$ to $1.4 \mathrm{~mm}$ \\
\hline Acan & Acanthocolax sp. nov. females & 1.9 to $2.3 \mathrm{~mm}$ \\
\hline Cali & Caliginae spp. & 1.4 to $2.5 \mathrm{~mm}$ \\
\hline Call & Caligidae larvae & 220 to $600 \mu \mathrm{m}$ \\
\hline Naup & Nauplii & 140 to $200 \mu \mathrm{m}$ \\
\hline UCop & Unidentified spp. & $280 \mu \mathrm{m}$ to $1.6 \mathrm{~mm}$ \\
\hline \multicolumn{3}{|c|}{ Isopoda } \\
\hline Gnat & Gnathia spp. larvae & $280 \mu \mathrm{m}$ to $2.7 \mathrm{~mm}$ \\
\hline Isop & Anilocra nemipteri and Anilocra sp. juv. & 4.2 to $23.0 \mathrm{~mm}$ \\
\hline \multicolumn{3}{|c|}{ Monogenea } \\
\hline Anop & Anoplodiscus spp. & $310 \mu \mathrm{m}$ to $1.6 \mathrm{~mm}$ \\
\hline Bene & Benedininae spp. & $340 \mu \mathrm{m}$ to $2.0 \mathrm{~mm}$ \\
\hline Dact & Dactylogyridea spp. & 170 to $600 \mu \mathrm{m}$ \\
\hline \multicolumn{3}{|c|}{ Digenea } \\
\hline TraL & Transversotrema licinum & $370 \mu \mathrm{m}$ to $1.7 \mathrm{~mm}$ \\
\hline $\mathrm{TraH}$ & Transversotrema haasi & 1.1. to $3.3 \mathrm{~mm}$ \\
\hline Tran & Transversotrema spp. & $600 \mu \mathrm{m}$ \\
\hline UDig & Other unidentified spp. & $220 \mu \mathrm{m}$ to $1.4 \mathrm{~mm}$ \\
\hline \multicolumn{3}{|c|}{ Turbellaria } \\
\hline Turb & Ichthyophaga and/or Paravortex spp. & $110 \mu \mathrm{m}$ to $1.3 \mathrm{~mm}$ \\
\hline \multicolumn{3}{|c|}{ Platyhelminthes } \\
\hline UFla & Unidentified flatworms & $200 \mu \mathrm{m}$ to $1.4 \mathrm{~mm}$ \\
\hline
\end{tabular}


approximately similar size were collected from within a species to reduce variation due to host size.

Locations. The number and composition of parasites (Table 1) among fish collected at 2 locations were examined. The collections at Lizard Island (January 1993) were from the above 3 sites. The collections at Heron Island (June 1993) were from 2 sites on the reef slope (2 to $10 \mathrm{~m}$ in depth) located on opposite sides of the island ( $2 \mathrm{~km}$ apart). Between 5 and 9 specimens were collected from the 7 species at each location. Sites at both locations were combined as the sample sizes of fish from both locations were too small and unbalanced to test for differences among sites.

Time. The number of parasites per fish on Hemigymnus melapterus and Thalassoma lunare was analyzed for differences among 3 collection times (seasons) at Lizard Island (May 1992, August 1992, January 1993). The remaining 5 species were tested for differences in parasite numbers between 2 collection times (May 1992, January 1993). Only H. melapterus and T. lunare had sufficient sample sizes at each time to test for differences in parasite composition among times. To obtain sufficient degrees of freedom for a multivariate analysis of variance, the number of variables was reduced by selecting parasite categories (Table 1) that were present in $30 \%$ or more of the fish. This reduced the parasite categories from 7 to 2 for T. Lunare (Gnathia spp. and unidentified Digenea spp.) and from 12 to 7 for $H$. melapterus (Gnathia spp., Hatschekia hemigymni, unidentified Digenea spp., Acanthocolax sp. nov. males and/or Orbitacolax sp. nov. males, Caligidae larvae, Orbitacolax sp. nov. females, and Turbellaria). The reduced variables constituted 90.1 and $98.4 \%$ of the total parasites respectively.

Fish size. The relationship between total parasite numbers per fish and standard length was investigated for all species collected at Lizard Island using linear correlation. The sample size of fish was increased by using fish collected at different times. So that time did not confound results, only fish species that had no significant differences in total number of parasites among times were used. Outliers (total parasites of an individual fish) were tested ( $t$-statistic) and omitted when $p<0.05$ ( $p$ corrected with Bonferroni's inequality).

Statistical analyses. Multifactor analysis of covariance (ANCOVA) was used to test for differences in the total number of parasites among species and sites as well as among species and locations with fish surface area as the covariable. For each species, a single-factor ANCOVA was used to test for differences in the total number of parasites per fish among times using fish standard length as the covariable. The slopes were not significantly different $(\mathrm{p}<0.05)$ in all ANCOVAs so the interaction term was dropped. Multifactorial multi- variate analysis of variance (MANOVA) was used to test for differences in the number of parasites per category among species and sites and among species and locations; a single-factor MANOVA was used to test for differences in the number of parasites per parasite category among times for each of the 2 species. All Transversotrema spp. at Heron Island were pooled to increase the degrees of freedom in the MANOVA. To discriminate among species and sites and among species and locations a canonical discriminant analysis (CDA) was used. The multivariate test statistic, Pillai's Trace, was used in all MANOVAs because it is more robust to heterogeneity of variance and is less likely to involve Type I error than comparable tests (Green 1979). To satisfy the assumptions of the statistical analyses performed, all data were natural-log $(x+1)$ transformed to achieve homogeneity of variance or linearity. Surface area was used as a covariable when making comparisons among species while standard length was used as a covariable when making comparisons within a species. Surface area was natural-log transformed to achieve linearity as was the standard length of Hemigymnus melapterus.

Capture of fish and parasite quantification. Fish were collected by a SCUBA diver herding 1 fish at a time into a $15 \times 1.6 \mathrm{~m}$ barrier net. Each fish was quickly captured with a hand net and immediately placed into a plastic bag. Parasites were recovered by soaking the fish in the anesthetic chloretone $10.4 \%$ BDH Chemicals, Poole, England) for 30 to $60 \mathrm{~min}$ following Hargis (1953), then rinsing the fish and filtering all liquids (Grutter unpubl.). The gills of all Hemigymnus melapterus, which contain many gill copepods, were removed and fixed prior to the chloretone soak. Because the thick mucus produced by Scarus sordidus blocks filters, for these specimens collected in January 1993 and June 1993, the plastic bag contents were filtered and the whole fish scanned under a stereo microscope $(20 x)$ for parasites.

Not all parasites were identified to species for 2 reasons. First, there is a general lack of information on ectoparasites of Australian fish species with very few identification keys available. Second, the study was designed as a quantitative study rather than a qualitative study with the emphasis placed on estimating the spatial and temporal variability of ectoparasites. A large sample size was required, thus it was beyond the scope of this study to identify parasites that were found only 1 or 2 times during the study. In addition, the multivariate tests could not be carried out with numerous variables (parasite species) due to insufficient degrees of freedom, nor with variables which consisted mainly of zeros. Therefore, as a consequence of the above constraints, it was necessary to combine some parasite species into broader categories (Table 1). 
Only some parasites could be identified using keys for Australian parasites (Bruce 1986, Lester \& Cannon 1988, Kabata 1991, Cribb et al, 1992). The remainder were examined by other workers and when possible identified. A few caligids were males and could not be identified further ( $Z$. Kabata pers. comm.). Due to difficulties in separating male Orbitacolax sp. nov. and Acanthocolax sp. nov, these were combined. The Caliginae are Pseudocaligus sp. nov. (on Acanthochromis polyacanthus, Siganus doliatus, and Scolopsis bilineatus), male Lepeophtheirus sp. (S. doliatus), male Caligus sp. ( $S$. doliatus, Scarus sordidus), and a male caligid on S. sordidus (Z. Kabata pers. comm.). Because adult caligids were relatively rare on all species, with a prevalence of only 0 to $16 \%$, all were combined for the statistical analyses under the category Caliginae spp. Caligidae larvae and nauplii were unidentifiable (Z. Kabata pers. comm.). The taxonomic characters of gnathiid isopods are based on adult males (Holdich $\&$ Harrison 1980); therefore, when live larvae were available, they were reared to adult males for identification (Grutter unpubl.). All reared larvae were Gnathia sp. nov., although examination of fixed juveniles suggested at least 1 more species (B. Cohen pers. comm.). The isopods are Anilocra sp. found on 1 individual of Hemigymnus melapterus, and Anilocra nemipteri (on $S$. bilineatus). Some of the dactylogyrideans were identified as ancyrocephaline (I. Whittington pers. comm.). Unidentified digenea consisted of Gyliauchea $\mathrm{sp}$. and other larvae which could not be identified (T. H. Cribb pers. comm.). Little is known about parasitic turbellarians of fish, as only 1 study in Australia has described turbellarians to 2 genera only (Lester \& Cannon 1988). These 2 genera were found (L. Cannon pers. comm.) and combined.

Although it has been shown that some parasites pass through the $200 \mu \mathrm{m}$ filter, which are recovered with the $57 \mu \mathrm{m}$ filter (Grutter unpubl.), the use of the $57 \mu \mathrm{m}$ filter is very time consuming as it quickly becomes blocked with fish mucus. Therefore, due to time constraints imposed by the large sample size, the $200 \mu \mathrm{m}$ filter was used for the site, temporal, and host size comparisons. An additional $57 \mu \mathrm{m}$ filter was used in January 1993 (Lizard Island) and June 1993 (Heron Island), therefore the location comparisons are based on parasites removed by both filters.

Fish. surface area was used as a covariable when making comparisons across species to standardize for differences in fish body size among species. Surface area was measured by removing paired fins, pinning all fins and body onto waterproof paper, and drawing an outline of the fish. The area of the outline was measured using the software Framegrabber 3.2 and Image 1.4. For some specimens, surface area was estimated from standard length with linear regressions as they were highly correlated ( $\mathrm{r} \geq 0.95$ ). To estimate the error associated with using an outline of the fish rather than the actual surface area, the surface area of the least laterally compressed species, Hemigymnus melapterus, was measured with aluminum foil. The outline area was $28.9 \%$ (SE 1.3) of the foil area. The species Acanthochromis polyacanthus, Ctenochaetus striatus, and Siganus doliatus are all very laterally compressed, so the error is probably less, while the shapes of the remaining 3 species are more similar to H. melapterus.

\section{RESULTS}

\section{Species and sites}

The total number of parasites per fish was different among species (Table 2). The covariable, surface area, was significant, indicating that it explained some of the variation, however after accounting for size the differences among species remained (Table 2). The total number of parasites per fish was not affected by the local area of collection (Table 2), so the total numbers of parasites for each site were pooled for each species for graphical display (Fig. 1). The mean total number of parasites per fish differed markedly among species (Fig. 1a). Hemigymnus melapterus had the most parasites, with a mean of 110 parasites fish $^{-1}$, Siganus doliatus and Scolopsis bilineatus had less, with slightly over 20 parasites fish $^{-1}$, and for Thalassoma lunare, Scarus sordidus, Ctenochaetus striatus, and Acanthochromis polyacanthus the numbers were lower, with 1 to 5 parasites fish $^{-1}$ (Fig. 1a). Although there was a trend for larger species to have more parasites than smaller species, the differences among species in parasite numbers were not entirely due to differences in standard length (Fig. 1a). Some larger species, such as Scarus sordidus and Ctenochaetus striatus, had few parasites compared to the somewhat smaller species $S$. bilineatus, which had 5 times as many parasites (Fig. 1a).

Table 2. Two-factor analysis of covariance of total number of parasites per fish from 7 fish species collected at 3 sites with fish surface area (natural-log transformed for linearity) as the covariable. Data are $\ln (x+1)$ transformed

\begin{tabular}{|lrrrr|}
\hline Source & df & MS & $F$ & $p$ \\
\hline Covariable: Area & 1 & 8.10 & 14.69 & 0.001 \\
Species & 6 & 29.52 & 53.53 & 0.001 \\
Site & 2 & 0.68 & 1.23 & 0.295 \\
Species $\times$ Site & 1.2 & 0.44 & 0.80 & 0.654 \\
Residual & 141 & 0.55 & & \\
\hline
\end{tabular}



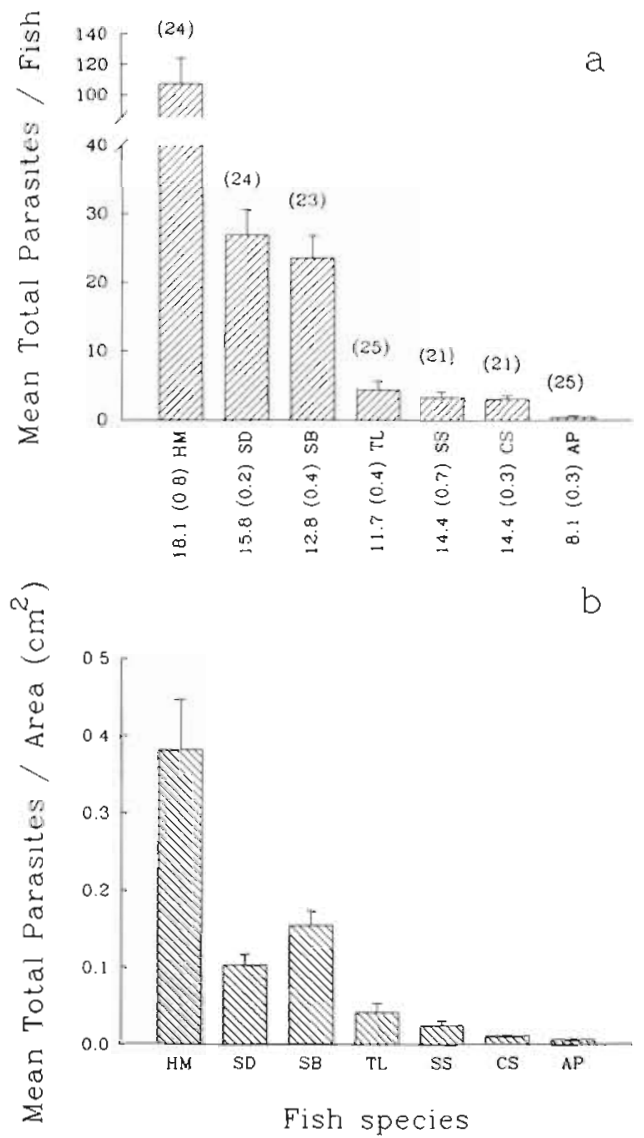

Fig. 1. Mean total parasites ( $\mathrm{SE}$ ) per species combined from 7 fish species collected at 3 sites in May 1992. (a) Mean number of parasites per species. The sample size of each species are in brackets above the means; the mean standard length (cm) (SE) of each fish species is on the $x$-axis. (b) Mean number of parasites per estimated surface area. HM: Hemigymnus melapterus; SD: Siganus doliatus; SB: Scolopsis bilineatus; TL: Thalassoma lunare; SS: Scarus sordidus; CS: Ctenochaetus striatus; AP: Acanthochromis polyacanthus

The above relationship was preserved when numbers of parasites were adjusted for size with some minor variations for Siganus doliatus (Fig. 1b). Due to the large surface area of the laterally compressed $S$. doliatus, the relative numbers of parasites on $S$. doliatus were less with respect to the other species when they were expressed as parasites per surface area than as parasites per fish (Fig. 1). Thus the shape of the fish can influence the relative difference in parasite abundance among species when it is expressed as surface area. Surface area is not easily measured, however it is curvilinear to weight and can be easily estimated $[\ln ($ area $)=2.19+0.67 \ln ($ weight $)](r=0.98)$.

There were differences in the types of parasites found on the 7 fish species (Table 3). The species site interaction in the MANOVA was significant which shows that the differences among species were not
Table 3. Multivariate factorial analysis of variance of numbers of parasites in all categories (except nauplii) from 7 fish species collected at 3 sites. Data are $\ln (x+1)$ transformed. Test statistic is Pillai's Trace. See Table 1 for parasite categories

\begin{tabular}{|lcccc|}
\hline Source & $F$ & $\begin{array}{c}\text { Numerator } \\
\mathrm{df}\end{array}$ & $\begin{array}{c}\text { Denominator } \\
\mathrm{df}\end{array}$ & $\mathrm{p}$ \\
\hline Site & 1.56 & 34 & 254 & 0.030 \\
Species & 8.56 & 102 & 786 & 0.001 \\
Site $\times$ Species & 1.33 & 204 & 1644 & 0.001 \\
\hline
\end{tabular}

consistent among sites (Table 3). The differences among species and sites were discriminated using CDA. Examination of a plot of the first 3 canonical discriminants (not displayed), which described $89 \%$ of the variation, revealed that the parasite assemblages of Hemigymnus melapterus, Scolopsis bilineatus, and Siganus doliatus were very different from the remaining species. $H$. melapterus was best characterized by Hatschekia hemigymni and Gnathia spp.; S. bilineatus by Transversotrema licinum, Anoplodiscus sp., and Acanthocolax sp. nov. females; and $S$. doliatus by Dactylogyridea spp. The variation due to sites was minor and was mainly attributable to relatively rare species present at some sites and not others (unidentified flatworms, Hatschekia sp. a, and Caliginae spp.) or to unidentified digenea which are probably internal parasites released post mortem (T. H. Cribb pers. comm.).

Because the differences among sites within a species were small compared to the species differences, the number of parasites per category was combined across the 3 sites to graphically summarize the overall abundance of the different parasites on each species (Fig. 2). The number of parasites in each category varied among species, with usually 1 or 2 parasite types dominating the parasite assemblage of a species (Fig. 2). Several types of parasites were common to most fish species at Lizard Island. Gnathiid isopods were found on all species and often were one of the most abundant parasites (Fig. 2). Turbellaria, although not very abundant, were found on Hemigymnus melapterus, Siganus doliatus, Scolopsis bilineatus, and Acanthochromis polyacanthus (Fig. 2a to $\mathrm{C}_{\mathrm{g}} \mathrm{g}$ ); unidentified Digenea spp. were found on all species except Ctenochaetus striatus (Fig. 2f), and unidentified flatworms were found on all species except $C$. striatus (Fig. 2f).

The number of parasite categories per species varied among the fish species at Lizard Island. Fish species with more total parasites per fish (Hemigymnus melapterus, Siganus doliatus, and Scolopsis bilineatus) had more parasite categories (10 to 13$)$ per species (Fig. 2a to c). The fish species with few parasites (Tha- 

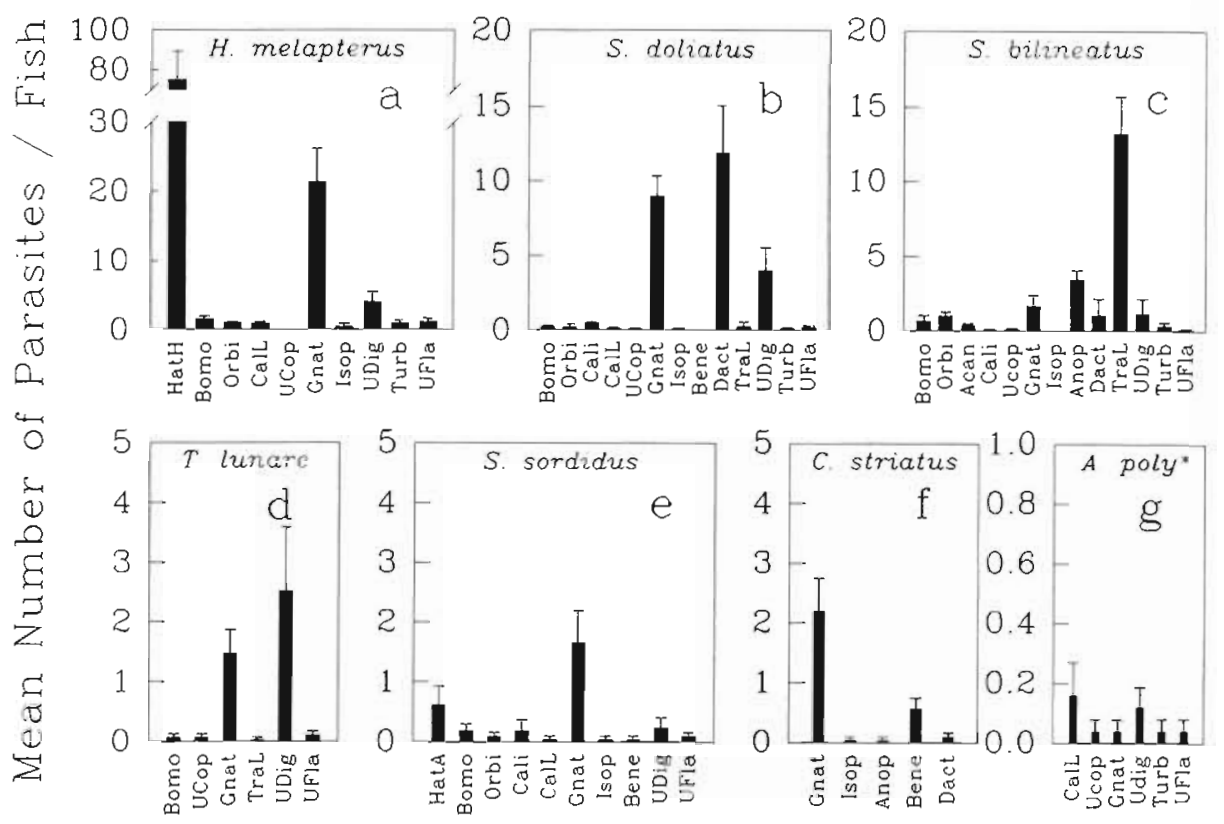

Parasite Category
Fig. 2. Mean number of parasites (+SE) per parasite category combined from 7 fish species collected at 3 sites in May 1992. "Acanthochromis polyacanthus. See Table 1 for parasite categories; see Fig. 3 for genus names lassoma lunare, Ctenochaetus striatus, and Acanthochromis polyacanthus) had few parasite categories (5 to 6; Fig. 2d, f, g), except for Scarus sordidus which had few parasites but had many (10) types of parasites (Fig. 2e).

\section{Locations}

The total number of parasites per fish was different among locations and species (Table 4). The covariable, surface area, was significant which indicates that it was responsible for some of the variation among locations and species (Table 4). The significant interaction term in the ANOVA was due to Hemigymnus melapterus, which had many more parasites at Heron Island, and to Siganus doliatus and Scolopsis bilineatus which had more parasites at Lizard Island (Fig. 3).

Table 4. Two-factor analysis of covariance of total numbers of parasites from 7 fish species collected at Lizard Island (January 1993) and Heron Island (June 1993) with fish surface area as the covariable. Parasite numbers were $\ln (x+1)$ transformed, surface area was natural-log transformed

\begin{tabular}{|lrrrr|}
\hline Source & df & MS & $F$ & $p$ \\
\hline Covariable: Area & 1 & 16.98 & 29.24 & 0.001 \\
Location & 1 & 6.46 & 11.13 & 0.001 \\
Species & 6 & 24.43 & 42.06 & 0.001 \\
Location $\times$ Species & 6 & 3.96 & 6.83 & 0.001 \\
Residual & 83 & 0.58 & & \\
\hline
\end{tabular}

The number of parasites per parasite category was also significantly different between locations and species (Table 5). The significant interaction term indicates that the differences in parasite categories were not consistent over locations (Table 5). CDA was used to discriminate between species and locations. A plot of the first 3 canonical discriminants (not displayed), which

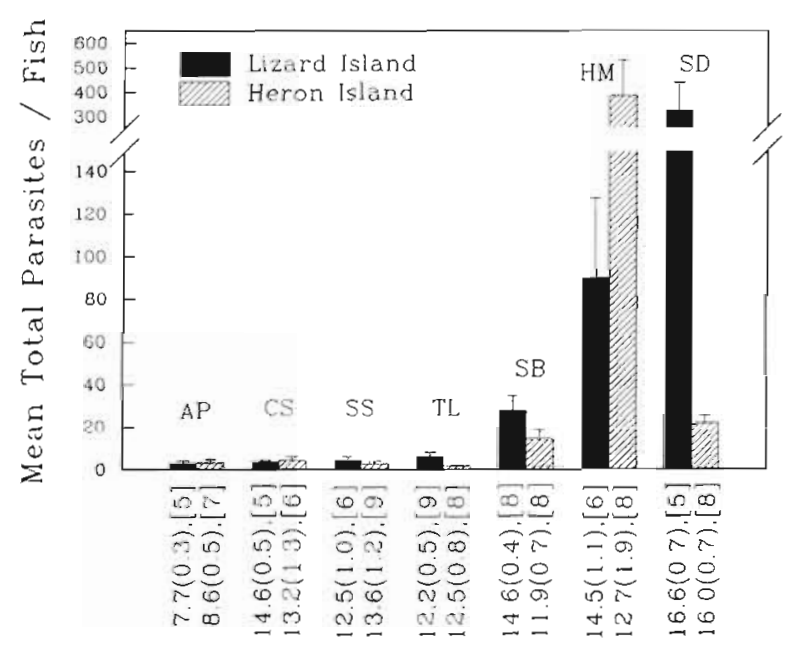

Fish Species

Fig. 3. Mean total parasites ( $+S E$ ) per fish from 7 fish species collected at Lizard Island and Heron Island. The mean standard length $(\mathrm{cm}),(\mathrm{SE})$ and [sample size] of each species is given. AP: Acanthochromis polyacanthus; CS: Ctenochaetus striatus: SS: Scarus sordidus; TL: Thalassoma lunare; SB: Scolopsis bilineatus; HM: Hemigymnus melapterus; SD: Siganus doliatus 
Table 5. Multivariate factorial analysis of variance of numbers of parasites in all categories (Transversotrema spp. were pooled) from 7 fish species collected at Lizard Island and Heron Island. Data are $\ln (x+1)$ transformed. Test statistic is Pillai's Trace

\begin{tabular}{|lrrrr|}
\hline Source & $F$ & $\begin{array}{c}\text { Numerator } \\
\mathrm{df}\end{array}$ & $\begin{array}{c}\text { Denominator } \\
\mathrm{df}\end{array}$ & $\mathrm{p}$ \\
\hline Lacation & 8.48 & 18 & 67 & 0.001 \\
Species & 5.69 & 108 & 432 & 0.001 \\
Location $\times$ Species & 2.68 & 108 & 432 & 0.001 \\
\hline
\end{tabular}

explained $87 \%$ of the variation, revealed that the parasite assemblages of Scolopsis bilineatus, and especially Hemigymnus melapterus and Siganus doliatus, from Lizard Island were different from the parasite assemblages of the same species from Heron Island. Most of the centroid means on the 3 canonical discriminants were the same sign, within a species, for the above 3 species. This indicates that the differences between locations for each species were due more to differences in number of parasites in a category than to differences in overall species composition. This is also demonstrated by comparing the numbers of parasites in each category between locations in Fig. 4. There were more Hatschekia hemigymni and copepod nauplii on H. melapterus collected from Heron Island than Lizard Island; fewer dactylogyrideans and Gnathia spp. on S. doliatus collected from Heron Island than Lizard Island (Fig. 4). For
$S$. bilineatus the differences are not as obvious but fish from Lizard Island had more categories and more parasites in the categories found at both places (Fig. 4).

All fish species from Lizard Island had more parasite categories than those at Heron Island (Fig 4). It is unlikely that this is a result of placing parasites from Heron Island into broader categories, such as unidentified Digenea spp., unidentified Copepoda spp. and unidentified flatworms, as these categories rarely had more parasites at Heron Island (Fig. 4). Most of the parasite categories found on fish from Heron Island were the same as those at Lizard Island. However one obvious exception was that Transversotrema haasi were found on most Scarus sordidus at Heron Island but never on any collected at Lizard Island (Figs. 2e \& 4e).

\section{Time}

Only Siganus doliatus had a significant difference in the total parasites per fish among collection times (ANCOVA; $F=13.87$, df $=1,26, \mathrm{p}<0.001$ ). The mean parasites per fish (SE) increased in May 1992 from 27.2 (3.7) to 177.2 (90.6) in January 1993, mainly due to an increase in Dactylogyridea spp. Therefore, for S. doliatus, only the data from May were used to investigate the relationship between parasite numbers and host length. The total number of parasites per fish for the other species was not different among collection times (ANCOVA; Acanthochromis polyacanthus $F=0.46$,
Fig. 4. Mean number of parasites $(+\mathrm{SE})$ per parasite category from 7 fish species collected at Lizard Island and Heron Island. 'Acanthochromis polyacanthus. See Table 1 for parasite categories; see Fig. 3 for genus names

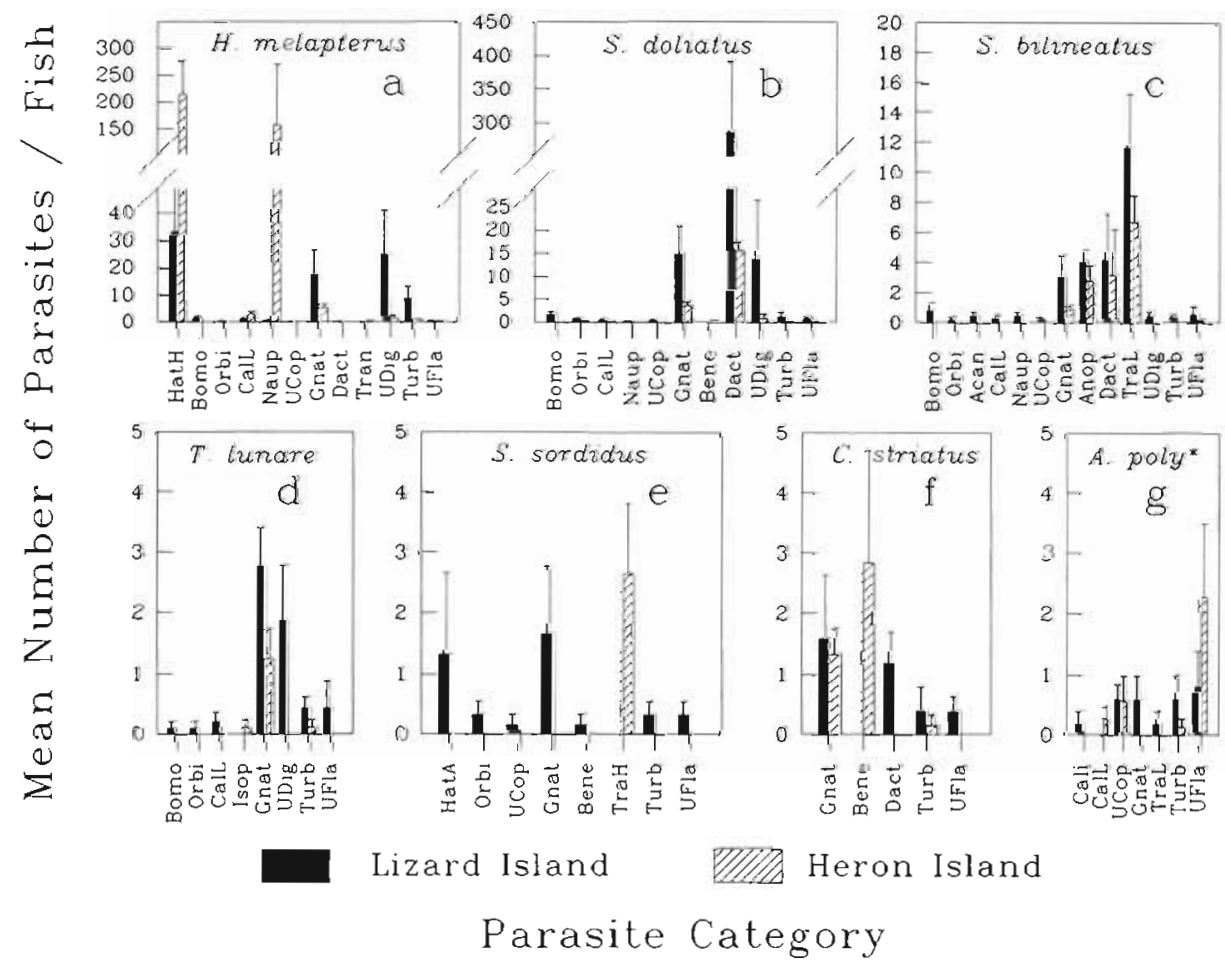




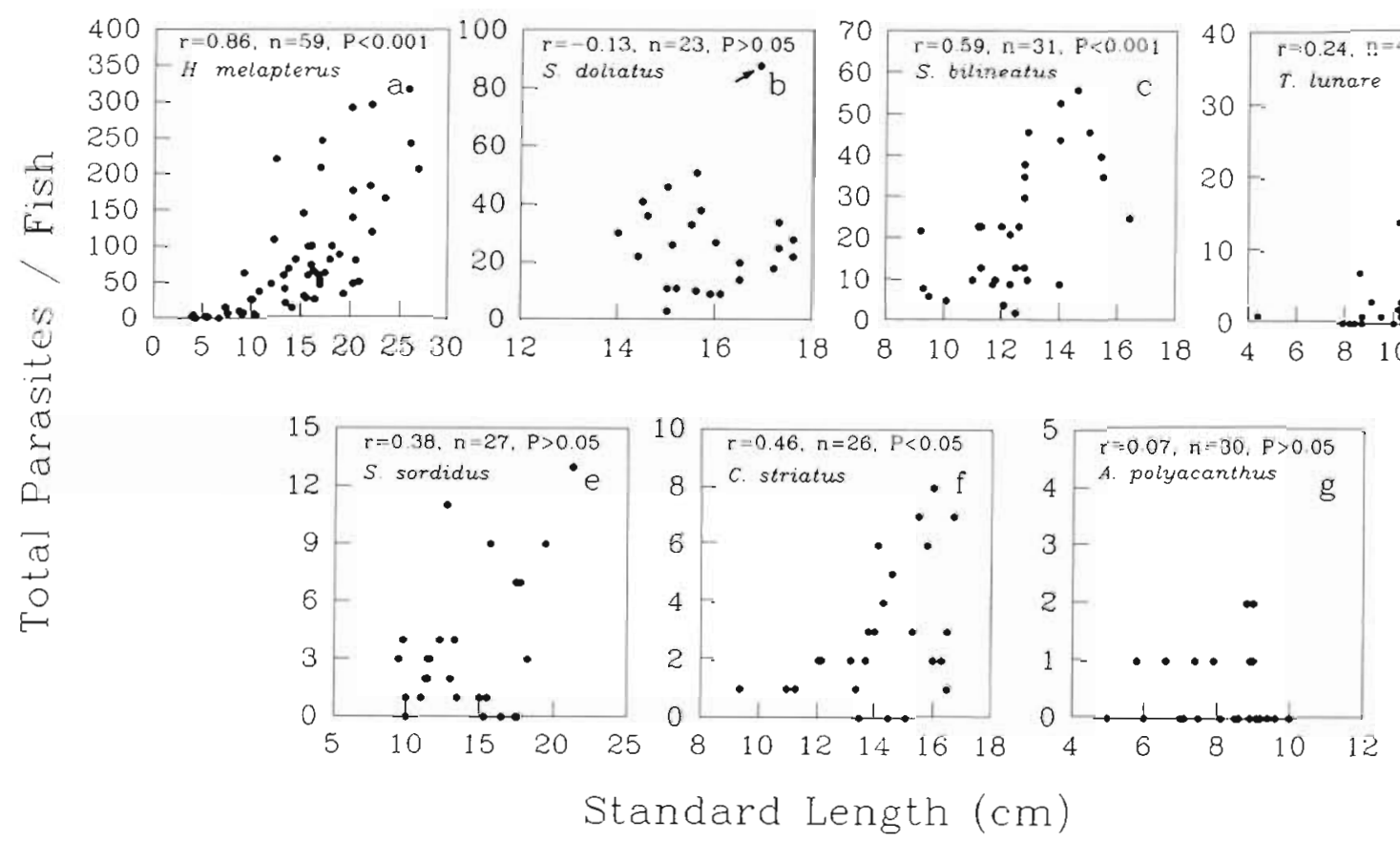

Fig. 5. Total parasites per fish against standard length of fish, with the correlation coefficient ( $\mathrm{r}$ ), the sample size ( $\mathrm{n}$ ), and significance level of the correlation for each of 7 species. The parasites of Hemigymnus melapterus were $\ln (x+1)$ transformed and the standard length natural-log transformed to satisfy the assumption of linearity in the correlation analysis. Outliers $(p<0.05)$ were not included in the analysis (labeled with an arrow). See Fig. 3 for genus names

$\mathrm{df}=1,27, \mathrm{p}=0.052 ;$ Ctenochaetus striatus $F=0.10, \mathrm{df}=$ 1,23, $p=0.759$; Scolopsis bilineatus $F=0.02, \mathrm{df}=1,28$, $\mathrm{p}=0.892 ;$ Scarus sordidus $F=0.09, \mathrm{df}=1,24, \mathrm{p}=0.772$; Thalassomá lunare $F=0.10, \mathrm{df}=2,43, \mathrm{p}=0.907$; Hemigymnus melapterus $F=0.19$, $d f=2,55, p=0.825$ ) and thus were pooled over times to investigate the parasite number/host size relationships of each species. The number of parasites per parasite category was not significantly different among collection times for $H$. melapterus (MANOVA; $F=1.42, \mathrm{df}=14,102, \mathrm{p}=0.157$ ) and $T$. lunare (MANOVA; $F=1.95, \mathrm{df}=4,4, \mathrm{p}=0.109$ ).

\section{Fish size}

There was a positive correlation between the total number of parasites per fish vs standard length for the species Hemigymnus melapterus, Scolopsis bilineatus, and Ctenochaetus striatus, but not for Acanthochromis polyacanthus, Siganus doliatus, Scarus sordidus, and Thalassoma lunare (Fig. 5).

\section{DISCUSSION}

The study demonstrates that most of the fish species investigated have a species-specific parasite abundance and fauna which is conserved over space and time. Al- though these fish species coexist in similar habitats, their parasite fauna varies greatly among species and mirrors the high diversity of coral reef fish species. Even taxonomically related species, such as Hemigymnus melapterus, Thalassoma lunare, and Scarus sordidus, had very different parasite assemblages. The differences observed in the parasite faunas may be influenced by differences among species in life span, mobility, gregarious habits, and size of host (Polyanski 1961a).

A large fluctuation in the parasite population of Siganus doliatus occurred at Lizard Island. Dactylogyridean monogeneans on $S$. doliatus increased 7 -fold from May 1992 to January 1993. It is well known that monogenean populations in cold waters are seasonal (Llewellyn 1959, Kennedy 1975); this study shows temporal fluctuations of monogeneans can also occur in the tropics. Such temporal variability in parasites may have important implications for host fish. For example, if host cleaning is influenced by parasite load, then it is likely that changes in parasites will be reflected in host fish cleaning behavior. It may also be representative of punctuated selection that may occur for host fish to respond to cleaner fish. Finally, it emphasizes the need for repeated sampling at different times.

Gnathia spp. was common among all the fish species investigated, and has also been found on 12 out of 25 other coral reef fish species examined $(n=218$; pers. obs.). Their mobility (Davies \& Johnston 1976, Grutter 
unpubl.) and their life history, which involves leaving the host to molt 3 times (Wägele 1988), may explain their low host specificity.

Although Lizard Island and Heron Island are over $1000 \mathrm{~km}$ apart and fish were collected at different times, the relative patterns of parasite abundance among fish species were similar between the 2 locations. The same fish species had low parasite loads at both locations. The largest differences were due to 1 or 2 parasite types being more abundant at one location than the other. For Siganus doliatus the difference between locations was probably an effect of time rather than location. Dactylogyridea spp. on $S$. doliatus from Lizard Island increased between May 1992 and January 1993 at Lizard Island while the numbers of Dactylogyridea spp. on fish from Heron Island in June 1993 were similar to those collected at Lizard Island in May 1992.

The fact that the numbers of parasite categories per fish species were lower at Heron Island than at Lizard Island may be due to latitudinal and/or temperature differences, as it has been shown that fish from high latitudes have fewer types of parasites (Dogiel 1961. Polyanski 1961b, Rohde 1977). Most of the parasites found on fish at Heron Island were found on fish from Lizard Island except for some monogenea. Byrnes \& Rohde (1992) also found that the geographical distributions of copepods and isopods among Acanthopagrus spp. (Sparidae) were very wide, while monogeneans were more restricted. Because the comparison presented here is confounded by time, no definite conclusions can be made about a location effect on the parasite assemblages. However, the comparison is still useful as it shows the similarity of the parasite assemblages between these 2 distant locations.

The relationship between parasite load and host size varied among fish species with Hemigymnus melapterus showing the strongest positive correlation, mainly due to the gill-inhabiting copepod Hatschekia hemigymni. Gill surface area also increases with size of fish (Hughes 1966), therefore the parasite load of $H$. melapterus species is more specifically a function of gill size. Larger fishes often have higher numbers of parasites (Noble et al. 1963, Cressey \& Collette 1971 , Buchmann 1989).

The fish species that had no clear correlation of parasite load with host size either had few parasites or were collected from a narrow size range which may have obscured the relationship between host size and parasite abundance. The absence of a positive correlation between parasite abundance and host size may also be a result of older hosts developing immunity to infestation (Noble et al. 1963) or due to the specialist/generalist nature of parasites (Cressey \& Collette 1971). The wide variety of parasites included in this analysis may also have obscured relationships between specific parasitic types and host size. The large differences in parasite load and species composition among species raise the questions of why such large differences occur in co-existing species, how they are reflected in cleaning behavior, and how the patterns are conserved over space and time.

Addendum. In a recent taxonomic review of the family Scaridae, Scarus sordidus has been renamed Chlorurus sordidus [Bellwood, D. R. (1994). A phylogenetic study of the parrotfishes family Scaridae (Pisces: Labroides), with a revision of genera. Rec. Aust. Mus. Supp]. 20: 1-86].

Acknowledgements. This work was funded by a 1992-1993 Australian Museum Postgraduate Grant, a Lizard Island Research Station Doctoral Fellowship 1993-1994, a P\&O Australia Limited/Heron Island Research Station Reef Research Fellowship 1993, and a J.C.U. Merit Research Grant 1994. Many thanks to G. Boxshall, L. Cannon, B. Cohen, T. Cribb, Z. Kabata, and I. Whittington for identifying some of the parasites, to $M$. Johnson for help in the field, and to the Lizard Island and Heron. Island Research Station staffs for their assistance. J. H. Choat, M. McCormick, D. Zeller, and anonymous reviewers provided valuable comments on the manuscript. I am indebted to N. Moltschaniwskj and A. Lewis for statistical advice.

\section{LITERATURE CITED}

Bortone, S. A., Bradley, W. K., Oglesby, J. L. (1978). The hostparasite relationship of two copepod species and two fish species. J. Fish Biol. 13: 337-350

Brooks, D. R., McLennan, D. A. (1993), Parascript: parasites and the language of evolution. Smithsonian Institution Press, Washington, DC

Bruce, N. L. (1986). Australian Pleopodias Richardson, 1910, and Anilocra Leach, 1818 (Isopoda: Cymothoidae), crustacean parasites of marine fishes. Rec. Aust. Mus. 39: $85-130$

Buchmann, K. (1989). Relationship between host size of Anguilla anguilla and infection level of the monogeneans Pseudodactylogyrus spp. J. Fish Biol. 35: 599-601

Byrnes, T., Rohde, K. (1992). Geographical distribution and host specificity of ectoparasites of Australian bream, Acanthopagrus spp. (Sparidae). Folia parasitol. 39: 249-264

Cannon, L. R. G. (1978). Marine cercariae from the gastropod Cerithium moniliferum Kiener at Heron Island, Great Barrier Reef. Proc. R. Soc. Qd 89: 45-77

Cannon, L. R. G. (1979). Ecological observations on Centhium moniliferum Kiener (Gastropoda: Cerithiidae) and its trematode parasites at Heron Island, Great Barrier Reef. Aust. J. mar. Freshwat. Res. 30: 365-374

Choat, J. H., Bellwood, D. R. (1985) Interactions amongst herbivorous fishes on a coral reef: influence of spatial variation. Mar. Biol. 89: 221-234

Cressey, R. F., Collette, B. B. (1971). Copepods and needlefishes: a study in host-parasite relationships. Fish. Bull. U.S. $68: 347-432$

Cribb, T. H., Bray, R. A., Barker, S. C. (1992). A review of the family Transversotrematidae (Trematoda: Digenea) with the description of a new genus, Crusziella. Invertebr. Taxon. 6: 909-935

Davies, A. J., Johnston, M. R. L. (1976). The biology of Haemogreganna bigemia Laveran \& Mesnil, a parasite 
of the marine fish Blennius pholis Linnaeus. J. Protozool. 23: $315-320$

Dogiel, V. A. (1961). Ecology of the parasites of freshwater fishes. In: Dogiel, V. A.. Petrushevski, G. K., Polyanski, $Y$ I. (eds.) Parasitology of fishes. Oliver and Boyd, Edinburgh, p. 1-47 (English translation)

Green, R. H. (1979). Sampling design and statistical methods for environmental biologists Wiley Interscience, New York

Greenwood, P. H., Rosen, D. E., Weitzman, S. H., Meyrs, G. S (1966). Phyletic studies of teleostean fishes, with a provisional classification of living forms. Bull. Am. Mus. Nat. Hist. 131: $339-456$

Hargis, W. J. (1953). Chloretone as trematode relaxer, and its use in mass-collecting techniques. J. Parasitol. 39(2) 224-225

Holdich, D. M., Harrison, K. (1980). The crustacean isopod genus Gnathia Leach from Queensland waters with descriptions of nine new species. Aust. J. mar. Freshwat Res. 31: 215-240

Hughes, G. M. (1966). The dimensions of fish gills in relation to their function. J. exp. Biol. 45: 177-195

Kabata, Z. (1991). Copepoda parasitic on Australian fishes, XIII: family Hatschekiidae. J. nat. Hist. 25: 91-121

Kennedy, C. R. (1975). Ecological animal parasitology. Blackwell Scientific Publ., Melbourne

Lester, R. J G., Cannon, L. R. G. (1988). Two turbellarians parasitic in fish. Dis. aquat. Org. 5: 15-22

Lester, R. J. G., Sewell, K. B., Barnes, A., Evans, K. (1988). Stock discrimination of orange roughy, Hoplostethus atlanticus by parasite analysis. Mar. Biol. 99: 137-143

Llewellyn, J. (1959). The larval development of two species of gastrocotylid trematode parasites from the gills of Trachurus trachurus. J. mar. biol. Ass. U.K. 38: 461-467

Noble, E. R., King, R. E., Jacobs, B. L. (1963). Ecology of gill

This article was presented by C. Birkeland, Mangilao, Guam parasites of Gillichthys mirabilis. Ecology 44: 295-305

Polyanski, Y. I. (1961a). Ecology of marine parasites. In: Dogiel, V. A., Petrushevski, G. K., Polyanski, Y I. (eds.) Parasitology of fishes. Oliver and Boyd Ltd, Edinburgh, p. 48-83 (English translation)

Polyanski, Y I. (1961b). Zoogeography of the parasites of USSR marine fishes. In: Dogiel, V. A., Petrushevski, G. K., Polyanski, Y l. (eds.) Parasitology of fishes. Oliver and Boyd Ltd, Edinburgh, p. 230-243 (English translation)

Randall, J. E., Allen, G. R., Steene, R. C. (1990). Fishes of the Great Barrier Reef and Coral Sea. Crawford House Press, Bathurst, NSW

Rawson, M. V. Jr (1976). Population biology of parasites of striped mullet, Mugil cephalus L. I. Monogenea. J. Fish Biol. 9: 184-194

Rohde, K. (1977). Species diversity of monogenean parasites of fish on the Great Barrier Reef. Proc. 3rd int. coral Reef Symp. 1: 585-591

Rohde, K. (1981). Population dynamics of two snail species, Planaxis sulcatus and Cerithium moniliferum, and their trematode species at Heron Island, Great Barrier Reef. Oecologia 49: $344-352$

Rohde, K., Sandland, R. (1973). Host-parasite relations in Lobatostoma manteri Rohde (Trematoda: Aspidogastrea). Z. ParasitenKd. 42: 1.15-136

Sindermann, C. J. (1986). Effects of parasites on fish populations: practical considerations. Int. J. Parasitol. 17: $371-382$

Wägele, J. W. (1988). Aspects of the life-cycle of the Antarctic fish parasite Gnathia calva Vanhöffen (Crustacea: Isopoda). Polar Biol. 8: 287-291

Yeo, S. T., Spieler, R. (1980). Habitat effects on the occurrence of parasites inhabiting the sergeant major, Abudebduf saxatilis (Linnaeus), with a list of parasites of Caribbean damselfishes. Bull. mar. Sci. 30: 313-324

Manuscript first received: March 16, 1994

Revised version accepted: August 10, 1994 